\title{
A review of the effects of using social stories to promote behavior, communication, and social skills for students with autism spectrum disorders (ASD)
}

\author{
Aiman Alkldi \\ Special Education, University of Jaddah, KSA \\ esalkaladi@uj.edu.sa
}




\title{
A review of the effects of using social stories to promote behavior, communication, and social skills for students with autism spectrum disorders (ASD)
}

\author{
Aiman Alkldi \\ Special Education, University of Jaddah, KSA \\ esalkaladi@uj.edu.sa
}

Received: $5^{\text {th }}$ Oct 2020 Revised: $25^{\text {th }}$ Jan 2021 Accepted: $5^{\text {th }}$ Feb 2021 DOI: https://doi.org/10.31559/CCSE2021.2.1.3

Abstract: The purpose of this paper was to provide a review of the literature on the effect of Social Stories intervention on improving behavior, and communication skills for students with autism spectrum disorders (ASD). Nine scholarly articles focused on the impact of using social stories strategy were reviewed. Five articles addressed the use of Social Stories exclusively. However, four studies were focusing on the effects of using technology to present Social Stories strategy. All the studies presented in this paper pointed to the effectiveness of the social story strategy in improving the targeted behaviors and some specific skills school students with ASD. Despite the findings of those studies, further research might be needed to determine the effects of using Social Stories. For example, improving skills for high school students who have ASD or implementation more Videos that present Social Stories for Children who have autism with high severity scores. In addition, capability to generalize the acquired skills by the impact of Social Stories strategy may need further examinations.

Keywords: Social Stories; Autism Spectrum Discords; Intervention.

\footnotetext{
*Corresponding author

Aiman Alkldi

Special Education, University of Jaddah, KSA

E-mail: esalkaladi@uj.edu.sa
} 


\section{Introduction}

About $1 \%$ of the world population has autism spectrum disorder and ASDs prevalence is estimated at one in 68 births in the United States (CDC, 2015). Autism disorder usually appears in children before the third year of age. It affects the child development in three ways: speaking coherently, social skills and communication with others, and how to behave in certain situations (American Psychiatric Association, 2013). Classic Autism, Asperger's syndrome, and Pervasive Developmental Disorders-Not Otherwise Specified (PDD-NOS) are pointed to the term Autism Spectrum Disorders (ASDs) (APA,2013). In recent research, people had affected by ASDs in a few diverse ways and range from mild to severe (Autism Society of America, 2015). Children with autism spectrum disorders (ASDs) have difficulties in their emotional, social, and non-verbal communication, and have a hard time understanding relationships. Moreover, some of them have repetitive patterns of behavior based on DSM-5.

Many children with ASDs may have mental illness or language impairment associated with autism. Most of them have few words, or they have no problem in pronunciation. However, they have difficulty to use the language effectively. They also have an inability to understand body language and nuances in voice tones (DSM-5) (APA,2013). Even though, children and adults with ASD have diverse capabilities; They have critical signs that including difficulties in speech, social and communication skills, and some restricted activities (Wing, 1996). These problems pose challenges to the development of natural abilities where skills are learned through school, home, and training (American Psychiatric Association, 2000). Social skills include communication skills but also requires the ability to interact in a manner which avoids inappropriate behavior. Hence, failure to begin communicating is likely to increases the risk of isolation from family, peers, and society (Bellini, S., Akullian, J., \& Hopf, A. ,2007a; Matson, J. L., Matson, M. L., \& Rivet, T. ,2007). Therefor, finding treatment that addresses a child's needs has become essential to improving their social communication skills (Wert, B. Y., \& Neisworth, J. ,2003; Baker, M. J., Koegel, R. L., \& Koegel, L. K. ,1998). Children with ASD could gain benefits from convenient interventions aimed at teaching suitable social initiation. For instance, greeting responses, initiating a conversation, and engaging in ongoing social interactions (Church et al. 2000; American Psychiatric Association 2000). Developing these types of behaviors considered an urgency to to promote the children who have ASD in integration with society. Furthermore, the ultimate goal of integrating students with ASDs in general education schools is to enhance the communicative abilities, academic and social skills, by providing opportunities to interact with teachers and peers in regular classrooms. However, students with ASD are less likely to take advantage of these 
opportunities due to their characteristics (Owen-DeSchryver et al., 2008). Variety effective interventions have been designed to fit the level of the child's skills and promote positive behaviors in specific areas of development, such as social communication. Children with ASDs need appropriate intervention that is evidence-based and fits the level of their communication difficulties (National Research Council, 2001).

Children who suffer from autism have a lack of "theory of mind" which allows individuals to understand the views of other people and the desires and beliefs. Social Story was built based on the "theory of mind". Thus, using Social Story is an intervention to explain the social attitudes in certain ways therefore reduce or remove the confusion and inability to predict (Gray \& Garand, 1993). Social Stories were created by a teacher "Carol Gray" in 1991 to share accurate social information, and to help children with ASD to develop their social skills (Gary, 2010). Social Stories (Gray \& Garand, 1993; Gray, 1994, 2010) which is also called "social narrative" are popular intervention techniques that are recommended for research and to investigate the behaviors, communication, and behavioral theories that advocate for children who have ASD (Gray \& Garand, 1993). Social Stories are short descriptions for situations or activities which are included specific information about what to expect and what to do in these situations. Social Stories consist a set of "descriptive", "perspective", and "directive" sentences which describes general topography of the situation description, the feeling expression, and the target behavior respectively. The main point of using Social Stories is to help children with ASDs in poor communication skills and low-level functioning (Ali, Frederickson, 2006). Social Story fully considered is accurately social status, skill, and the idea that teachers and practitioners want to deliver to the child according to ten criteria. These criteria discussed in full in gray will help in social story development to ensure the quality of the story in terms of story content, significance, and perception of physical and social safe state for listener. For example, to establish a Social Story, it should have a title, clear introduction to define the subject, body to add details, and conclusion to reinforces and summarizes the information in the story (Gary, 2004).

In general, observational studies indicate that social stories use in huge range of applications. For instance, helping children with autism to understand how others might behave or respond in a particular situation, thus learning how to behave the same way. Also, developing self-care skills for children with ASD. Moreover, it is providing positive feedback about areas of strength and achievement in order to develop the independence and raising the confidence for those children (Norris \& Dattilo, 1999; Cullain, 2000; Kuoch \& Mirenda, 2003; Crozier \& Tincani, 2005). Many of these studies regarding the role that could be played by the social stories are published in upbringing of children journals. Therefore, the choice of 
research is significant in two ways: 1) teachers can help fill the gap that children with ASDs suffer through knowledge of the actual role of the social stories; 2) teachers can find the right way to encourage sound growth of children (Gray, 2010; Gray, 1994). In addition, the main objective in Social Stories is to gain understanding of the subject of the story, thus improving ability to apply the appropriate behavior, reaction, and good disposition in a general social situation.

By relying on visual learning through images, it seems that featuring educational social stories strategy is an adequate idea for children with ASD and other developmental disabilities. Whereas, when the images have been sequenced in systematic arrangement and thoughtful manner; the main idea will be communicated to the child. Hence, the Social story will help children to follow the desirable behavior (Baker, el. 1998).

Given the indications that the use of Social Story is beneficial, it is important to review what is known about Social Story and its effects on students with ASD. Although there were some reviews of literature on the effects of using Social Story strategy with students who have ASD; the review of (Hodes, 2014) has focused specifically on the impact of Social Story in one area (i.e., disruptive behavior). The author addressed specific forms of Social Story strategies to reduce a disruptive behavior with children with autistic spectrum disorder in the United Kingdom. The author started to find articles which use social stories as interventions, using the participants who had Autism Spectrum Disorder or empirical language. In this study the author has looked to discus area which is the increasing appropriate behaviors and engaging communication. The author has looked to the peer-interviewed articles to narrow what the author found. Also, the author has looked to specific aged from six to fourteen because the author was looking for the school setting, in an educational establishment. These interventions would take place in school. The articles in Hodes's review look for using social stories strategy to help students with ASD to decrease their disruptive behavior. The difference between Hodes' review and my review is that target of behavior. Hodes is looking to decrease inappropriate behavior, and the researcher was looking to increase appropriate behavior. All teachers and parents are looking to help their children to engage in society and school with peers. Children with ASD have difficulties in a proper engagement, communication, and social skills. We need to increase that.

The other review (Bradshaw, C. P., Waasdorp, T. E., \& Leaf, P. J. ,2015) which focused on the design method that used in each article published from 1993 to 2012. Leaf was focused on single subject method and exclude any comparative study. However, in this study the researcher used articles published from 2000 to 2015 period time, so there are more than two studies were not founded in Leaf review. Moreover, leaf studied the effectiveness of using Social Story 
whether in terms of reducing unwanted behavior, as well as increasing the appropriate behaviors. In contrast, in this study the focused was on the impact of using of Social Story to increase appropriate behaviors and social communication.

The intent of this paper is to add further analyzed review to the literature on the effects of Social Story intervention on improving the skills of students with ASD. The research question is what the effects of the Social Story strategy in are promoting positive behavior, appropriate communication. Also, increasing their social skills in students with ASD?

\section{Method}

\section{Search Procedure:}

To investigate the impact of Social Stories' strategy, the researcher first conducted a hand and online search of secondary sources addressing Social Story, such as books and informally published articles, to identify the best Social Story used in effective intervention. Any strategy that involves a typical teacher's work with students with ASD that can be identified as Social Story intervention has resulted in a good number of such interventions. However, the search procedure in this step led to a reduction in this number by identifying locations and identifying scholarly articles.

The next step was to locate and identify scholarly articles that has been tested out the Social Story interventions. The articles were in scholarly journals and magazines within same databases. The indexes database was from an American-based resource that contains a wide range of international literature that including articles from journals, books, monographs, and dissertations. This was done by using four major search engines, ERIC, SAGE, PsycINFO, and GOOGLE SCHOLAR. With these search engines, the researcher used different combinations of the following terms: autism; autism spectrum disorders; students with ASD; children with Asperger's syndrome; Social Story intervention; Social Narrative; and communications, social skills, and positive behaviors. To make the searches more precise, the researcher narrowed them by using and by limiting the results to Social Story articles that shown in Table 1.

\section{Selection Criteria:}

This review included several studies based on the following criteria. First, the intervention included participant's characteristics and dependent variables. Second, Social Stories interventions had to be implemented and published in peer reviewed journal from 2000 to 2015 . Third, the sample had to include at least one student who has aged through school (6-14 years) and who had been previously diagnosed with an ASD or impaired language. Fourth, the procedure and what the participants did during the study had to be explained in detail. Finally, the dependent variables had to be a behavior, communicative, or social skill (increasing interacting with others). The researcher excluded articles that used Social Stories to decrease disruptive behaviors. The 
International Journal of Childhood, Counselling, \& Special Education (CCSE), Volume2, Issue: 1, March: 2021, pp.35-52

searches based on these criteria reviewed in this paper (see Table 1 for resulted in a total of nine studies to be information about the studies).

Table (1): Information on the Studies about the effects of Social Story intervention on improving the communication skills and appropriate behaviors of students with ASD

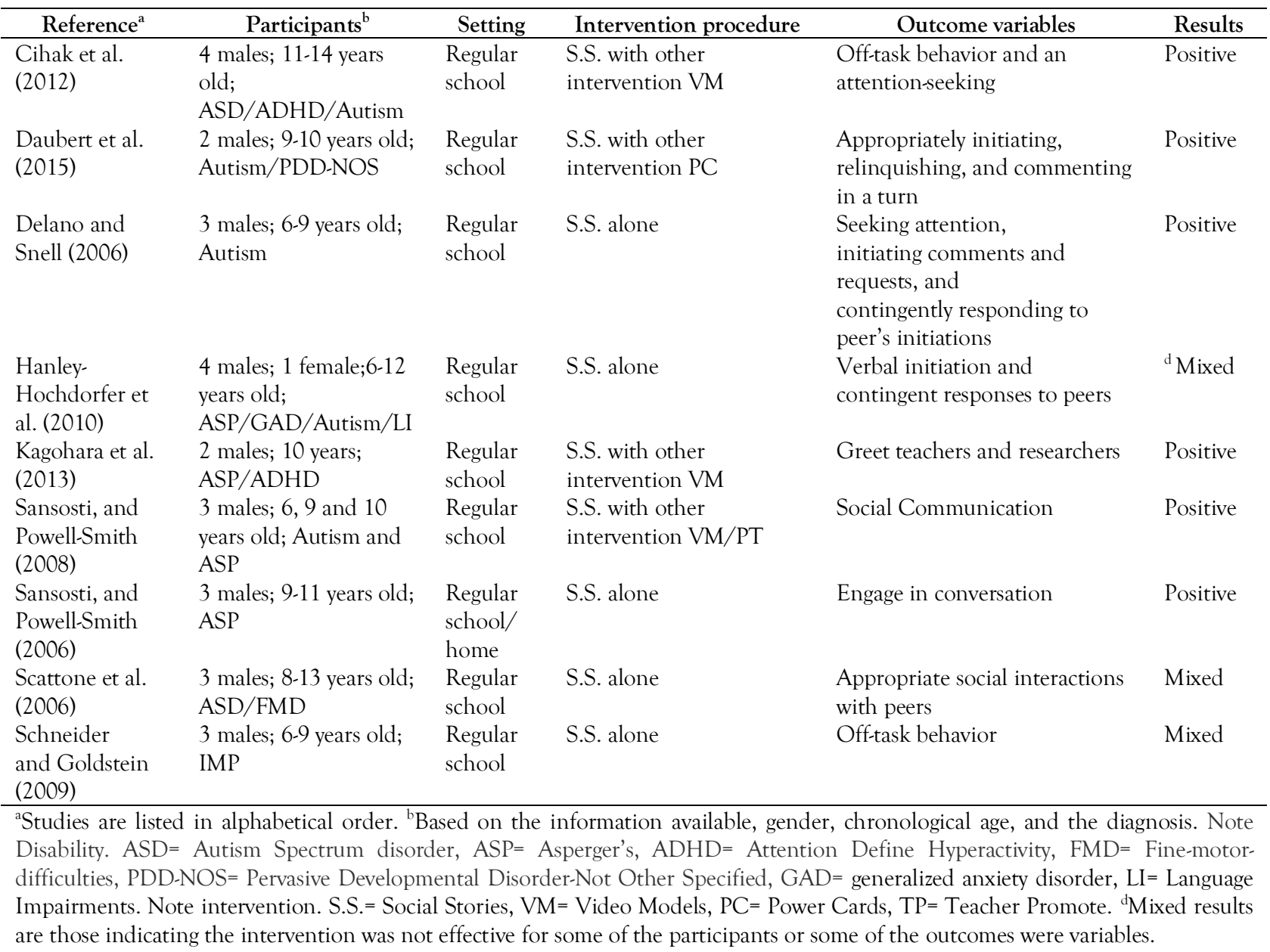

\section{Social Stories exclusively:}

Five articles invested the using of social stories a lone which were by Scattone et al. (2006), Sansosti \& Powell-Smith (2006), Delano \& Snell (2006), Schneider \& Goldstein (2009), and Hanley-Hochdorfer et al. (2010). Classroom teachers, psychological specialists, speech-language pathologists, and parents nominated the participants to be included in these studies. The participants from these five studies were selected to increase appropriate social interaction, which was identified as verbal initiation to peers and adults (e.g., cheering, responses, or greeting), and engaging in conversation (e.g., asking questions, requesting information, objects, or actions). Delano \& Snell (2006) and Hanley-Hochdorfer et al. (2010) selected the sample based on that all participants had an existing diagnosis of ASD or language impairment, problems in social and behavior skills, and not received any direct treatment for one year or longer. Articles had 
chosen the sample based on that all participants had an existing diagnosis of ASD. Participants did not start or maintain conversations with others, and they had inappropriate responses to their peers (Scattone et al., 2006; Delano \& Snell, 2006).

The overall sample from these studies is the targeted population of students with ASD as it covers different ages and in educational settings. Moreover, the sample has included 25 boys and only 2 girls. Hanley-Hochdorfer et al. (2010) suggested that whole participants may have a different presentation of social difficulties. So, they compiled a profile which contains 20 items that show general information about the child, his/her abilities, and influence factors on behaviors, as well as visual analyses. That profile was called "the intervention rating profile."

In all studies, the Social Story was individually designed, meeting each child's case in terms of his/her social, behavior, and academic skills. A Social Story that was designed especially for individual participants was focused on development and enhancement of communication skills for students with ASD to encourage social interaction and conversation engagement. Scattone et al. (2006); Schneider \& Goldstein (2009); Hanley-Hochdorfer et al. (2010) identify that the Social Story in a book format should be appropriate for intervention in educational settings, and they identify the Social Story format by describing Social Story as: book size in terms of length and width; number of pages; number of sentences; kind of sentences (e.g., descriptive, perspective sentences); font type; story name; comprehension questions; who should read the story? (e.g., students or teacher or parents, or the first investigator). In addition, authors determined the appropriate time to read the story, session times during intervention, and observation checklists. Two studies by Sansosti \& Powell-Smith (2006) and Delano \& Snell (2006) illustrated Social Story by real pictures or cartoons; In contrast, Scattone et al. (2006), Delano \& Snell (2006) and Hanley-Hochdorfer et al. (2010) did not. Given the results of the studies that have been used social story alone, I found that there is considerable variation in the results. There is a study showed no effect of Social Story on the target behavior and indicated that the cause was the effect of overseeing the experiment. Also, three studies have variation in the relative impact because there are some limitations that got by the presence of confounded variables such as the influence of teachers promote and peers' effects. These limitations impact on the advantage of social story. Some suggested were using other interventions to support Social Story; However, others suggested that the use of Social Story alone is necessary to show up the strength and weakness of Social Story effectiveness.

Using Social Stories and electronic devices / cards to present Social Story:

Currently, instruments and tools have evolved in the classroom, often including a computer, video, and/or a smart blackboard. These tools have become an important factor in 
development and assistant education and interventions. Four of nine studies that written by Sansosti \& PowellSmith (2008), Cihak et al. (2012), Kagohara et al. (2013), and Daubert et al. (2015) used video or computer or Power cards to present Social Stories. Combining these strategies may have great value in the intervention field. Two studies by Sansosti \& PowellSmith (2008) and Cihak et al. (2012) focused on using videos on computer or IPad to show Social Stories to students with ASD. In another, video models were used as a support for the Social Stories strategy as happened in the research by Powell-Smith (2008), and Kagohara et al. (2013). Each student made a Social Story video which could be implemented as a Social Story for teaching social skills by school staff. In the same vein, a Power Card strategy was used to apply Social Story in a miniature easily usable way such as in Daubert et al. (2015).

In Cihak et al. (2012), each student had two stories illustrated by the video. The first one is aimed at reinforcing teacher attention (e.g., raising hand to request help); the second aims at a brief break such as raising hand for requesting a $10 \mathrm{~s}$ break. Each participant in the articles by Sansosti \& Powell-Smith (2008), and Kagohara et al. (2013) had one Social Story that designed according to Gray's (1998, 2002) which were constructed using Microsoft PowerPoint and video modeling. Then, it was presented to the children by using either a computer or iPad during lesson break. Both were conducted to target behavior related to social communication skills like greeting behavior, joining in, and sharing. In the experiment by Daubert et al. (2015) had been used three games and "the Power Card" which was based on the idea of social story. Those strategies were focused to increase three targeted behaviors such as initiating, leaving, and commenting appropriately turn. The studies showed improving in increasing a specific targeted behavior comparing with baseline and showed more increasing in the level of the targeted behavior after using Video Models. Limitations where it was difficult to separate the effects of using Social Stories and other technique.

For moral considerations' reason, three studies had involved the parents to get their feedback and modification on the social stories to ensure the appropriateness prior using.

\section{Participants:}

All the participants in these studies were students who had been identified as having ASD. Nine of them had been identified as having Asperger syndrome and ADHD. Two of children who have ADHD were taking medication to treat the hyperactivity. Three of participants had been identified as having ASD and impaired language. Seven children received speech and language services weekly for $30 \mathrm{~min}$ to $2 \mathrm{hr}$ at discontinuous intervals during a day, and one child received specialized support with math. One study did not report the name of the student participants. The majority of the participants' students were male. There was a total of 27 participants ranging from kindergarten and 
elementary school age to middle school age $(6-14$ years old). Approximately $22 \%$ were kindergarten students, $67 \%$ were elementary school students, and $11 \%$ middle school.

\section{Setting:}

All research studies had taken a place in educational organizations. The interventions were conducted during normal school hours at participants' schools which had special education services including autism needs. Three students attended fully integrated private school. One of participants attended a university-based program for children with disabilities. Three students were taking intervention sessions during kindergarten in a classroom center. Some of participants were taking the interventions in a separate room during recess time. Some participants have read the story at home by their parents help. The results were uncertain and failure in achieving its purpose which led to the proposal of further research and more investigation that focuses on the place of application.

\section{Overall Study Characteristics:}

nine studies comprised the overall review. They ranged in publication date from 2000 to 2015. This search was based on specific inclusion and exclusion criteria and reading the articles' abstracts. However, the author excluded many articles for considerable reasons. They did not acquire the primary research, and they managed other issues. For example, play skills, mealtime skills, physical activity skills, and parents and teacher's perspectives (Barry et al., 2004; Dev, Poonam,
2014; Menear, K. S., \& Neumeier, W. H., 2015; Hutchins, T. L., \& Prelock, P. A., 2013). A few articles in the literature were a Meta-analysis research, also some of them demonstrate how to create Social Stories and how to apply those (Kokina et al., 2010). Even though these articles were not included, the author has used this research for obtaining background information on using Social Stories' strategy. By completing these processes, there were nine articles that need to be reviewed. All of them addressed the frequency of behaviors, communications, and social skills. Articles appeared in several databases and some of them were included in previous reviews and meta-analysis. That is to ensure the literature was relevant to the subject searched.

Details of the participants' age, target behavior, study design, using pictures or photographs, and collaborative strategies are presented in Table 2 in the appendix. In addition to Social Story, one study focused on reducing inappropriate behaviors. This study has been reported to give a general picture of the Social Story's uses to modify behaviors and social skills. Five studies focused on the using of Social Stories' intervention to promote appropriate behaviors, communications, and social skills. However, the other four studies concentrated on using Social Story and electronic devices to present Social Story. These studies have looked at the impact of Social Story and the use of electronic devices as a support strategy to engagement and communication skills of children with ASD. The nine 
research articles were published in specialist journals that cover a range of ages and behaviors.

\section{Results}

The aim of this review was to find out whether Social Stories helped to increase appropriate behaviors to improving communication and social skills on children with ASD. The nine articles showed variable success for many participants, the way of use, materials, and patterns in the research.

Following that, Reynhout and Carter (2007) introduced tapping as a disruptive behavior and looked to decrease it in their study. The specific behavior has been equally distributed in variable intervals across the observation period. The result showed reduction in the targeted behavior 'tapping' during the intervention comparing to the baseline. In contrast, study of Hanley-Hochdorfer et al. (2010) found Social Story intervention was unsuccessful on increasing appropriate behaviors. That because the percentage of overlapping data of contingent responses for participants were $(31 \%, 36 \%, 31 \%$, and $11 \%)$; whereas any responses less than $50 \%$ is suggestive of an unreliable intervention as mentioned in (Scruggs Mastropieri, 1985-86; Scruggs Mastropieri, 1998). However, four studies that used Social Stories strategy alone found effectiveness in increasing specific social engagement skills during the school day (Scattone et al., 2006; Sansosti \& Powell-Smith, 2006; Delano \& Snell, 2006; and Schneider $\&$ Goldstein, 2009). For example, the overall percentage of overlapping data for appropriate behaviors was $88 \%$ in (Schneider and Goldstein, 2009). That percentage indicates fine intervention effects (Scruggs Mastropieri, 1985-86; Scruggs Mastropieri, 1998). Similarly, the studies that used Social Story with other strategies found that Social Story interventions were effective and a fine way to help students with specific social, communication, social skills. These experiments met with acceptance desirable for teachers and children (Sansosti and Powell-Smith, 2008; Cihak et al., 2012; Kagohara et al., 2013; and Daubert et al., 2015).

Sample size seems appropriate in all nine research articles which is consisted of two to four participants; however, one article conducted a study that involving a single participant. The nine studies were used Multiple-probeacross-participants design which introduced a further phases or intervention. Sansosti and PowellSmith (2006), Delano and Snell (2006) and Hanley-Hochdorfer et al. (2010) introduced 'fade' phases following the intervention. Table 1 shows the description of outcomes for all nine studies. Six studies showed a positive result for using a social story strategy, and three studies showed mixed results.

\section{Discussion}

Social Stories use analyses the division of behavioral objectives into separate and sequential steps to achieve the larger goal of social communications through appropriate behaviors. Vocalizations and visual cues are used in Social Story strategy to help children with ASD to understand 
the story and apply the appropriate behavior (Gray, 1995). Social Stories' content is a model for an adequate behavior where there is repetition of social communication for target behavior and giving the opportunity to apply and practice (Barry et al., 2004).

Chan and O'Reilly (2008) suggested that taking a child's reading and comprehension levels into account when creating stories could be a possible factor for explaining the variance in the effectiveness of Social Stories as interventions. Kokina and Kern's meta-analysis (2010) found that outcomes were improved if the children's comprehension levels were checked before the Social Stories interventions were utilized.

In the studies that have been collected, those who have used Social Story strategy as an alone intervention on children with ASD found that using of Social Story strategy was effective. They found Social Stories promote positive behaviors and social communications, as well as effective to complete one task, especially when that Social Story was presented by images (Sansosti \& Powell-Smith, 2006; Delano \& Snell, 2006; HanleyHochdorfer et al., 2010). On the other hand, studies that have used Social Story strategy made it clear that there is positive impact on the level of social skills for children with ASD. However, it needs to take consideration of the previous studies that recommend using other interventions with Social Story. For instance, studies by (Sansosti \& Powell-Smith, 2008; Cihak et al., 2012; Kagohara et al., 2013; and Daubert et al., 2015) have indicated that there is a positive impact in the use of social story strategy when combined with other interventions such as using a computer or iPad or video modeling to view the Social Story by children with ASD. Advantage of technology could enhance Social Stories by making them more effective in improving appropriate behavior, communication, and social skills in the experiences on children who have ASD. Findings of the study by Sansosti, and PowellSmith also reflected Social Story was acceptable intervention to parents and teachers.

Children with ASD could find some situations difficult or stressful to them, for example, joining in a game. However, Social Stories could be used to explain these social situations and the adequate behavior in simple language.

A sample of Social Story "joining in a game" was presented in the appendix of Sansosti \& Powell-Smith (2006) study to apply Social Stories' criteria. The Social Story presented, contains at least four to five types of sentences (descriptive, perspective, affirmative, and directive). To apply the findings of this paper, educators may consider the following suggestions. Teachers of students with ASD should consider involving typical peers in classroom and non-classroom activities in which their students with ASD engage. Given the results of the studies, the Social Stories activities that used with participants were very similarly to the activities found in their classroom. Social engagement increased during play session during intervention time. Some of students 
had a higher rate of target behavior and communication skills. Improved task engagement and seek attentions for participants after viewing video Social Story. It seems that social stories with other techniques is more effective, but for the purpose of the study we need to do more research about using Social Stories alone.

\section{Limitations}

Even though a small number of studies founded that were conducted the effectiveness of Social Stories that have used on children with ASD to improve increasing appropriate behaviors. Also, a limitation in the studies which was attributed to the lack of pictures in the story, or to the experiences needed to support Social Stories in conjunction with other interventions. There are other limitations in this review, such as teachers' roles, and methods disadvantages. Instant Social Stories do not contain pictures could be related a lack of success of the intervention. Differences in participants' abilities, motivations, and age may affect the validity. Some of studies had difficulties to determine whether the outcomes were result of the technology or the strategies. One of limitation of my study is that the researcher had a small sample. If the researcher had a large sample, the researcher could have more specific evidence. Also, the researcher had covered many types of using social stories. If the researcher had just focused on one, maybe the researcher could be able to look more carefully in how effectiveness one type of using Social Stories. Finally, few studies which is focusing on raising the level of appropriate behaviors and communication skills compared with studies which are looking at reducing non-appropriate behavior by using social stories.

\section{Implications and future research}

The researcher review has shown that we need more empirical research in this area, which is looking specially to address Social Stories as alone implication. It's good to consider the topic from a broader perspective, as the use of Social Stories do not give a definite promise, but it may be a creative way to help children who have autism to increase and raise the level of social communication skills and more integration in the community. Because many of the studies did not address the effectiveness of Social Stories to enhance the appropriate behaviors, then to generalize newly acquired skills to new environments. As consequently, further research is needed to examine the impact of Social Stories strategy on increasing the appropriate behaviors and promoting generalization. In addition to the need for examining these areas, further research will be required to address the following aspects. First, because the target population in the studies were kindergarten, elementary, and middle schools; further research is necessary to examine the outcome of Social Stories strategy on appropriate skills for older students (i.e., high school, after high school). Furthermore, many of the participants in the studies was diagnosed with level of ASD that require support or substantial support 
(APA, 2013), therefore, the effects of Social Stories on those students who have impairments in behavior and communication skills need further examinations.

\section{References}

Ali, S., \& Frederickson, N. (2006). Investigating the evidence base of social stories. Educational Psychology in Practice, 22(4), 355-377, https://doi.org/10.1080/0266736060099 9500.

American Psychiatric Association. (2013). Diagnostic and statistical manual of mental disorders (DSM-5®). American Psychiatric Pub.

American Psychological Association, sponsoring body, issuing body. (2020). Publication manual of the American Psychological Association: the official guide to APA style. (Seventh edition.). American Psychological Association.

Baker, M. J., Koegel, R. L., \& Koegel, L. K. (1998). Increasing the social behavior of young children with autism using their obsessive behaviors. Journal of the Association for persons with Severe Handicaps, 23(4), 300-308, https://doi.org/10.2511/rpsd.23.4.300. Barry, L. M., \& Burlew, S. B. (2004). Using social stories to teach choice and play skills to children with autism. Focus on Autism and Other Developmental Disabilities, 19(1), 45-51, https://doi.org/10.1177/1088357604019 0010601.

Bellini, S., Akullian, J., \& Hopf, A. (2007). Increasing social engagement in young children with autism spectrum disorders using video self- modeling. School

Psychology

Review, 36(1), 80-90, https://doi.org/10.1080/02796015.2007. 12087953.

Bradshaw, C. P., Waasdorp, T. E., \& Leaf, P. J. (2015). Examining variation in the impact of school-wide positive behavioral interventions and supports: Findings from a randomized controlled effectiveness trial. Journal of Educational Psychology, 107(2), 546 , https://doi.org/10.1037/a0037630.

Center for Disease Control and Prevention. (2015). Autism Spectrum Disorder (ASD): Data $\mathcal{E}$ statistics. from http://www.cdc.gov/ncbddd/autism/data .html

Chan, J. M., \& O'Reilly, M. F. (2008). A Social Stories ${ }^{\mathrm{TM}}$ intervention package for students with autism in inclusive classroom settings. Journal of applied behavior analysis, 41(3), 405-409, https://doi.org/10.1901/jaba.2008.41405.

Church, C., Alisanski, S., \& Amanullah, S. (2000). The social, behavioral, and academic experiences of children with Asperger syndrome. Focus on autism and other developmental disabilities, 15(1), 12-20, https://doi.org/10.1177/1088357600015 00102.

Cihak, D. F., Kildare, L. K., Smith, C. C., McMahon, D. D., \& QuinnBrown, L. (2012). Using video social stories $^{\mathrm{TM}}$ to increase task engagement for middle school students with autism spectrum disorders. Behavior Modification, 36(3), 399-425, https://doi.org/10.1177/0145445512442 683.

Crozier, S., \& Tincani, M. J. (2005). Using a modified social story to 
decrease disruptive behavior of a child with autism. Focus on Autism and Other Developmental Disabilities, 20(3), 150157 ,

https://doi.org/10.1177/1088357605020 0030301.

Cullain, R. E. (2002). The effects of social stories on anxiety levels and excessive behavioral expressions of elementary school-aged children with autism.

Daubert, A., Hornstein, S., \& Tincani, M. (2015). Effects of a Modified Power Card Strategy on Turn Taking and Social Commenting of Children with Autism Spectrum Disorder Playing Board Games. Journal of Developmental $\mathcal{E}$ Physical Disabilities, 27(1), 93-110, https://doi.org/10.1007/s10882-0149403-3.

Delano, M., \& Snell, M. E. (2006). The Effects of Social Stories on the Social Engagement of Children with Autism. Journal of Positive Behavior Interventions, $\quad 8(1), \quad 29-42$, https://doi.org/10.1177/1098300706008 0010501.

Dev, P. C. (2014). Using social stories for students on the autism spectrum: teacher perspectives. Pastoral Care in Education, 32(4), 284-294, https://doi.org/10.1080/02643944.2014. 974662.

Facts and Statistics | Autism Society. (n.d.). Retrieved October 18, 2015, from http://www.autismsociety.org/what-is/facts-and-statistics/. Gray, C. (2000). Writing social stories with Carol Gray [Videotape and workbook]. Arlington, TX: Future Horizons.

Gray, C. (2010). The new social story book. Future Horizons.
Gray, C. A. (1994). Comic Strip Conversations: Illustrated interactions that teach conversation skills to students with autism and related disorders. Future Horizons.

Gray, C. A. (1998). Social stories and comic strip conversations with students with Asperger syndrome and highfunctioning autism. In Asperger syndrome or high functioning autism? (pp. 167- 194). New York, NY: Plenum.

Gray, C. A., \& Garand, J. D. (1993). Social stories: Improving responses of students with autism with accurate social information. Focus on Autism and Other Developmental Disabilities, 8(1), 110 ,

https://doi.org/10.1177/1088357693008 00101.

Hanley-Hochdorfer, K., Bray, M. A., Kehle, T. J., \& Elinoff, M. J. (2010). Social Stories to Increase Verbal Initiation in Children with Autism and Asperger's Disorder. School Psychology Review, 39(3), 484-492, https://doi.org/10.1080/02796015.2010. 12087767.

Hutchins, T. L., \& Prelock, P. A. (2013). Parents' Perceptions of Their Children's Social Behavior: The Social Validity of Social Stories ${ }^{\mathrm{TM}}$ and Comic Strip Conversations. Journal of Positive Behavior Interventions, 15(3), 156-168, https://doi.org/10.1177/1098300712457 418.

Kagohara, D. M., Achmadi, D., van der Meer, L., Lancioni, G. E., O'Reilly, M. F., Lang, R., ... \& Sigafoos, J. (2013). Teaching two students with Asperger syndrome to greet adults using social stories $^{\mathrm{TM}}$ and video modeling. Journal of Developmental and Physical Disabilities, 25(2), 241-251, 
International Journal of Childhood, Counselling, \& Special Education (CCSE), Volume2, Issue: 1, March: 2021, pp.35-52

https://doi.org/10.1007/s10882-012-

9300-6.

Kokina, A., \& Kern, L. (2010). Social Story $^{\mathrm{TM}}$ Interventions for Students with Autism Spectrum Disorders: A Meta-Analysis. Journal of Autism $\mathcal{B}$ Developmental Disorders, 40(7), 812-826, https://doi.org/10.1007/s10803-009-

0931-0.

Kuoch, H., \& Mirenda, P. (2003). Social story interventions for young children with autism spectrum disorders. Focus on Autism and Other Developmental Disabilities, 18, 219-227. Matson, J. L., Matson, M. L., \& Rivet, T. T. (2007). Social-skills treatments for children with Autism Spectrum Disorders: An overview. Behavior Modification, 31, 682-707, https://doi.org/10.1177/0145445507301 650.

Menear, K. S., \& Neumeier, W. H. (2015). Promoting Physical Activity for Students with Autism Spectrum Disorder: Barriers, Benefits, and Strategies for Success. Journal of Physical Education, Recreation EF Dance, 86(3), 43-48,

https://doi.org/10.1080/07303084.2014. 998395.

National Research Council. (2001). Educating children with autism. Washington, DC: National Academy Press.

Norris, C., \& Dattilo, J. (1999). Evaluating effects of a social story intervention on a young girl with autism. Focus on Autism and Other Developmental Disabilities, 14, 180-186, https://doi.org/10.1177/1088357699014 00307.

Owen-DeSchryver, J. S., Carr, E. G., Cale, S. I., \& Blakeley-Smith, A.
(2008). Promoting social interactions between students with autism spectrum disorders and their peers in inclusive school settings. Focus on Autism and other developmental disabilities, 23(1), 15-28, https://doi.org/10.1177/1088357608314 370.

Ozonoff, S., Dawson, G., \& McPartland, J. C. (2014). A Parent's Guide to High-functioning Autism Spectrum Disorder: How to Meet the Challenges and Help Your Child Thrive. Guilford Publications.

Reynhout, G., \& Carter, M. (2007). Social Story Efficacy with a Child with Autism Spectrum Disorder and Moderate Intellectual Disability. Focus on Autism $\mathbb{E}$ Other Developmental Disabilities, 22(3), 173-182, https://doi.org/10.1177/1088357607022 0030401.

Rhodes, C. (2014). Do Social Stories help to decrease disruptive behaviour in children with autistic spectrum disorders? A review of the published literature. Journal of Intellectual Disabilities, $\quad$ 18(1), 35-50, https://doi.org/10.1177/1744629514521 066.

Sansosti, F. J., \& Powell-Smith, K. A. (2006). Using Social Stories to Improve the Social Behavior of Children with Asperger Syndrome. Journal of Positive Behavior Interventions, $8(1)$, https://doi.org/10.1177/1098300706008 0010601.

Sansosti, F. J., \& Powell-Smith, K. A. (2008). Using Computer-Presented Social Stories and Video Models to Increase the Social Communication Skills of Children with High- 
International Journal of Childhood, Counselling, \& Special Education (CCSE), Volume2, Issue: 1, March: 2021, pp.35-52

Functioning Autism Spectrum

Disorders. Journal of Positive Behavior Interventions, 10(3), 162-178, https://doi.org/10.1177/1098300708316 259.

Scattone, D., Tingstrom, D. H., \& Wilczynski, S. M. (2006). Increasing appropriate social interactions of children with autism spectrum disorders using Social Stories ${ }^{\mathrm{TM}}$. Focus on Autism and Other Developmental Disabilities, 21(4), 211-222, https://doi.org/10.1177/1088357606021 0040201.

Schneider, N. s. o. e., \& Goldstein, H. (2009). Social Stories Improve the OnTask Behavior of Children with Language Impairment. Journal of Early Intervention, 31(3), 250-264, https://doi.org/10.1177/1053815109339 564.

Wert, B. Y., \& Neisworth, J. (2003). Effects of video self-modeling on spontaneous requesting in children with autism. Journal of Positive Behavior Interventions, 5(1), 30-34, https://doi.org/10.1177/1098300703005 0010501.

Wing, L. (1997). The autistic spectrum. The lancet, 350(9093), 1761 1766. 
International Journal of Childhood, Counselling, \& Special Education (CCSE), Volume2, Issue: 1, March: 2021, pp.35-52

\section{Appendix}

Table (2): Details of: references, participants' age $\mathcal{E}$ numbers, target behavior, study design, Social Story (S.S.) ratio, and the use of pictures/photographs/video/ electronic devices.

\begin{tabular}{|c|c|c|c|c|c|c|c|c|c|c|c|c|c|}
\hline Refrence & $\mathbf{n}$ & Age & Disability & Target Behavior & $\begin{array}{l}\text { Study } \\
\text { Design }\end{array}$ & Setting & $\begin{array}{c}\text { Using } \\
\text { pictures } \\
\text { / } \\
\text { photogr } \\
\text { aphs/ in } \\
\text { S.S. }\end{array}$ & $\begin{array}{l}\text { Observat } \\
\text { ion } \\
\text { Setting }\end{array}$ & $\begin{array}{l}\text { Interve } \\
\text { ntion } \\
\text { Length }\end{array}$ & $\begin{array}{l}\text { Interven } \\
\text { tion } \\
\text { conduct } \\
\text { ing }\end{array}$ & $\begin{array}{c}\text { S.S } \\
\text { alo } \\
\text { ne }\end{array}$ & $\begin{array}{c}\text { S.S. } \\
\text { with } \\
\text { othe } \\
\mathbf{r} \\
\text { inte } \\
\text { rven } \\
\text { tion } \\
\end{array}$ & $\begin{array}{l}\text { Descript } \\
\text { ion of } \\
\text { Outcom } \\
\text { es }\end{array}$ \\
\hline $\begin{array}{l}\text { Scattone et } \\
\text { al. (2006) }\end{array}$ & 3 & $8-13$ & $\begin{array}{l}\mathrm{ASD}=2 \\
\mathrm{ASD} / \\
\mathrm{FMD}=1\end{array}$ & $\begin{array}{l}\text { Appropriate social } \\
\text { interactions with } \\
\text { peers for all three } \\
\text { participants }\end{array}$ & $\begin{array}{l}\text { Multiple } \\
\text { baseline }\end{array}$ & $\begin{array}{l}\text { During } \\
\text { free time } \\
\text { activity }\end{array}$ & No & $\begin{array}{l}\text { 10-min } \\
\text { during } \\
\text { one free } \\
\text { time } \\
\text { activity. } 3 \\
\text { days per } \\
\text { week. }\end{array}$ & 11 week & $\begin{array}{l}\text { Trained } \\
\text { graduate } \\
\text { students }\end{array}$ & Yes & No & $\begin{array}{l}\text { The } \\
\text { achieveme } \\
\text { nt was not } \\
\text { the same } \\
\text { level of } \\
\text { positive } \\
\text { behavior } \\
\text { (Partial } \\
\text { evidence) }\end{array}$ \\
\hline $\begin{array}{l}\text { Sansosti, \& } \\
\text { Powell- } \\
\text { Smith } \\
(2006)\end{array}$ & 3 & $\begin{array}{l}10 \\
y \& 1 \mathrm{~m} \\
11 \mathrm{y} \& 6 \\
\mathrm{~m} \\
9 \mathrm{y} \& 9 \\
\mathrm{~m}\end{array}$ & $\mathrm{ASP}=3$ & $\begin{array}{l}\text { Engage in } \\
\text { conversation for all } \\
\text { three participants }\end{array}$ & $\begin{array}{l}\text { Multiple } \\
\text { baseline }\end{array}$ & $\begin{array}{l}\text { Participa } \\
\text { nts' } \\
\text { caregivers } \\
\text { who } \\
\text { responsib } \\
\text { le for } \\
\text { reading\& } \\
\text { reviewing } \\
\text { S.S. at } \\
\text { home/ } \\
\text { school }\end{array}$ & Yes & $\begin{array}{l}\text { Participan } \\
\text { ts' schools } \\
\text { during } \\
\text { regular } \\
\text { school } \\
\text { hours }\end{array}$ & $\begin{array}{l}15 \text {-min } \\
\text { observati } \\
\text { on } \\
\text { periods } 3 \\
\text { times per } \\
\text { week }\end{array}$ & $\begin{array}{l}\text { School } \\
\text { psycholo } \\
\text { gy } \\
\text { graduate } \\
\text { student } \\
\text { for }\end{array}$ & Yes & No & $\begin{array}{l}\text { Effectiv } \\
\text { (Partial } \\
\text { evidence) }\end{array}$ \\
\hline $\begin{array}{l}\text { Hanley- } \\
\text { Hochdorfer } \\
\text { et al. (2010) }\end{array}$ & 4 & $6-12$ & $\begin{array}{l}\text { ASP/ } \\
\mathrm{GAD}=1 \\
\mathrm{ASP}=1 \\
\text { Autism=1 } \\
\text { Autism/LI= } \\
1\end{array}$ & $\begin{array}{l}\text { Verbal initiation and } \\
\text { contingent responses } \\
\text { to peers for all four } \\
\text { participants }\end{array}$ & $\begin{array}{l}\text { Multiple } \\
\text { baseline }\end{array}$ & $\begin{array}{l}\text { Trained } \\
\text { readers to } \\
\text { impleme } \\
\text { nt the } \\
\text { S.S. } \\
\text { interventi } \\
\text { on in } \\
\text { quite } \\
\text { corner of } \\
\text { classroom } \\
/ \text { hallway } \\
4 \text { time } \\
\text { per week }\end{array}$ & No & $\begin{array}{l}\text { Conducte } \\
\text { d } 3 \text { times } \\
\text { per week } \\
\text { in lunch } \\
\text { time }\end{array}$ & $\begin{array}{l}15 \text {-min } \\
\text { observati } \\
\text { on } \\
\text { period by } \\
11 \text { week } \\
6 \text { weeks' } \\
\text { follow-up }\end{array}$ & $\begin{array}{l}\text { Trained } \\
\text { observer } \\
\mathrm{s}\end{array}$ & Yes & No & $\begin{array}{l}\text { Limited } \\
\text { support } \\
\text { (No } \\
\text { convincin } \\
\mathrm{g} \\
\text { evidence) }\end{array}$ \\
\hline $\begin{array}{l}\text { Schneider } \\
\text { \& Goldstein } \\
\text { (2009) }\end{array}$ & 3 & $6-9$ & $\mathrm{IMP}=3$ & $\begin{array}{l}\text { One task behavior } \\
\text { One task behavior } \\
\text { One task behavior\& } \\
\text { social skills }\end{array}$ & $\begin{array}{l}\text { Multiple } \\
\text { baseline }\end{array}$ & $\begin{array}{l}\text { First } \\
\text { author } \\
\text { read S.S. } \\
\text { to each } \\
\text { participa } \\
\text { nt each } \\
\text { day } \\
\text { before } \\
\text { school } \\
\text { routine }\end{array}$ & Yes & $\begin{array}{l}15 \mathrm{~s} \\
\text { during } 5 \text { - } \\
\text { min in } \\
\text { math class } \\
\text { routine }\end{array}$ & $\begin{array}{l}5 \text { times } \\
\text { per week } \\
5 \text { weeks } \\
\text { follow-up }\end{array}$ & $\begin{array}{l}\text { research } \\
\text { er }\end{array}$ & Yes & No & $\begin{array}{l}\text { At least } \\
\text { effective } \\
\text { (Partial } \\
\text { evidence) }\end{array}$ \\
\hline $\begin{array}{l}\text { Delano \& } \\
\text { Snell (2006) }\end{array}$ & 3 & $6-9$ & Autism $=3$ & $\begin{array}{l}\text { Seeking attention } \\
\text { Initiating comments } \\
\text { and requests } \\
\text { Contingently } \\
\text { responding to peer's } \\
\text { initiations }\end{array}$ & $\begin{array}{l}\text { Multiple- } \\
\text { probe- } \\
\text { across- } \\
\text { participan } \\
\text { ts }\end{array}$ & $\begin{array}{l}\text { Kinderga } \\
\text { rten } \\
\text { classroom } \\
\text { during } \\
\text { center } \\
\text { time. } \\
\text { Elementa } \\
\text { ry school } \\
\text { during a } \\
\text { break } \\
\text { time }\end{array}$ & No & $\begin{array}{l}\text { Four 10- } \\
\text { min } \\
\text { session }\end{array}$ & $\begin{array}{l}15 \\
\text { intervent } \\
\text { ion } \\
\text { sessions }\end{array}$ & $\begin{array}{l}\text { First } \\
\text { author } \\
\text { and } \\
\text { special } \\
\text { educatio } \\
\mathrm{n} \\
\text { teacher }\end{array}$ & Yes & No & $\begin{array}{l}\text { Improved } \\
\text { task } \\
\text { behavior } \\
\text { (convinci } \\
\text { ng } \\
\text { evidence) }\end{array}$ \\
\hline $\begin{array}{l}\text { Daubert et } \\
\text { al. (2015) }\end{array}$ & 2 & $9 \cdot 10$ & $\begin{array}{l}\text { PDD-NOS= } \\
1 \\
\text { Autism }=1\end{array}$ & $\begin{array}{l}\text { Appropriately } \\
\text { initiating a turn, } \\
\text { relinquishing a turn, } \\
\text { and commenting for } \\
\text { two participants }\end{array}$ & $\begin{array}{l}\text { Single- } \\
\text { subject, } \\
\text { Multiple } \\
\text { probe } \\
\text { across } \\
\text { condition }\end{array}$ & $\begin{array}{l}\text { Public } \\
\text { school, } 3 \text { - } \\
5^{\text {th }} \text { grade } \\
\text { self- } \\
\text { containe } \\
\text { d } \\
\text { classroom } \\
\text { At social } \\
\text { skills } \\
\text { block } \\
\text { period }\end{array}$ & Yes & $\begin{array}{l}\text { At social } \\
\text { skills } \\
\text { block } \\
\text { period }\end{array}$ & $\begin{array}{l}27 \text { session } \\
\mathrm{s}\end{array}$ & $\begin{array}{l}\text { research } \\
\text { er }\end{array}$ & No & $\begin{array}{l}\text { Yes } \\
\text { (Pow } \\
\text { er } \\
\text { Card } \\
\text { s) }\end{array}$ & $\begin{array}{l}\text { Effective } \\
\text { in } \\
\text { increasing } \\
\text { the target } \\
\text { (convinci } \\
\text { ng } \\
\text { evidence) }\end{array}$ \\
\hline $\begin{array}{l}\text { Cihak et al. } \\
\text { (2012) }\end{array}$ & 4 & $\begin{array}{l}11.12 . \\
13.14\end{array}$ & $\begin{array}{l}\text { ASD/ } \\
\text { ADHD }=2 \\
\text { Autism }=2\end{array}$ & $\begin{array}{l}\text { Attention-seeking \& } \\
\text { Task-Avoidance } \\
\text { behaviors }\end{array}$ & B-A-B & $\begin{array}{l}\text { All } \\
\text { phase's } \\
\text { study } \\
\text { occurred } \\
\text { in general } \\
\text { educatio }\end{array}$ & Yes & $\begin{array}{l}\text { 15-min in } \\
\text { duration } \\
\text { per } \\
\text { session }\end{array}$ & $\begin{array}{l}\text { Minimu } \\
\mathrm{m} 2 \\
\text { sessions } \\
\text { for each } \\
\text { phase }\end{array}$ & $\begin{array}{l}\text { Trained } \\
\text { special } \\
\text { educatio } \\
\mathrm{n} \\
\text { teacher }\end{array}$ & No & $\begin{array}{l}\text { Yes } \\
\text { VM }\end{array}$ & $\begin{array}{l}\text { Improved } \\
\text { task } \\
\text { engageme } \\
\mathrm{nt} \\
\text { (convinci } \\
\mathrm{ng}\end{array}$ \\
\hline
\end{tabular}


International Journal of Childhood, Counselling, \& Special Education (CCSE), Volume2, Issue: 1, March: 2021, pp.35-52

\begin{tabular}{|c|c|c|c|c|c|c|c|c|c|c|c|c|c|}
\hline & & & & & & $\begin{array}{l}\mathrm{n} \text { math } \\
\text { class }\end{array}$ & & & & & & & evidence) \\
\hline $\begin{array}{l}\text { Sansosti, } \\
\text { and } \\
\text { Powell- } \\
\text { Smith } \\
(2008)\end{array}$ & 3 & $\begin{array}{l}6-y \& 6 \\
\mathrm{~m} \\
9-y \& 3 \\
\mathrm{~m} \\
8-\mathrm{y} \& 10 \\
\mathrm{~m}\end{array}$ & $\begin{array}{l}\text { ASP }=1 \\
\text { Autism }=2\end{array}$ & $\begin{array}{l}\text { Greeting behaviors } \\
\text { Joining in } \\
\text { Sharing } \\
\text { (Social } \\
\text { Communication) }\end{array}$ & $\begin{array}{l}\text { Multiple- } \\
\text { baseline } \\
\text { across- } \\
\text { participan } \\
\text { ts }\end{array}$ & $\begin{array}{l}\text { Each } \\
\text { video was } \\
45 \mathrm{~s} \text { to } \\
1 \mathrm{~min} \\
\text { duration } \\
\text { Social } \\
\text { Stories } \\
\text { were } \\
\text { presented } \\
\text { by } \\
\text { PowerPoi } \\
\text { nt }\end{array}$ & Yes & $\begin{array}{l}\text { During } \\
\text { recess } \\
\text { time } \\
\text { during } \\
\text { regular } \\
\text { school } \\
\text { hours }\end{array}$ & $\begin{array}{l}15 \text { to } 20 \\
\text { min, two } \\
\text { times per } \\
\text { week } \\
4 \text { weeks }\end{array}$ & $\begin{array}{l}\text { Trained } \\
\text { graduate } \\
\text { students }\end{array}$ & No & $\begin{array}{l}\text { Yes } \\
\text { VM } \\
\text { TP }\end{array}$ & $\begin{array}{l}\text { Positive } \\
\text { effects } \\
\text { (Partial } \\
\text { evidence) }\end{array}$ \\
\hline $\begin{array}{l}\text { Kagohara et } \\
\text { al. (2013) }\end{array}$ & 2 & 10 & $\begin{array}{l}\mathrm{ASP} / \\
\mathrm{ADHD}=2\end{array}$ & $\begin{array}{l}\text { Greet teachers and } \\
\text { researchers }\end{array}$ & $\begin{array}{l}\text { Multiple- } \\
\text { baseline } \\
\text { across } \\
\text { participan } \\
\text { ts }\end{array}$ & $\begin{array}{l}\text { During } \\
\text { lesson } \\
\text { breaks or } \\
\text { in } \\
\text { separate } \\
\text { room }\end{array}$ & Yes & $\begin{array}{l}\text { Each } \\
\text { observer } \\
\text { sat } \\
\text { opposite } \\
\text { the trainer }\end{array}$ & $\begin{array}{l}2-3 \\
\text { times a } \\
\text { week } \\
\text { with one } \\
\text { session } \\
\text { per day }\end{array}$ & trainer & No & $\begin{array}{l}\text { Yes } \\
\text { VM }\end{array}$ & $\begin{array}{l}\text { Improving } \\
\text { task } \\
\text { greeting } \\
\text { (Partial } \\
\text { evidence) }\end{array}$ \\
\hline
\end{tabular}

Note Disability. ASD= Autism Spectrum disorder, ASP= Asperger's, ADHD= Attention Define Hyperactivity, FMD= Fine-motor-difficulties, PDD-NOS= Pervasive Developmental Disorder-Not Other Specified, $\mathrm{GAD}=$ generalized anxiety disorder, LI= Language Impairments. Note intervention. S.S.= Social Stories, VM= Video Models, TP= Teacher Promote. 